\title{
Thematic Representation and Linguo-Cognitive Structure of the Businesswoman Image from the Perspective of Gender-Professional Axiology
}

\author{
Tatyana Yu. Tameryan' ${ }^{1} \varangle$, Irina A. Zyubina ${ }^{2} \mathbb{D}$, Alla V. Dzhigkaeva ${ }^{3}$ \\ ${ }^{1}$ North Ossetian State University, \\ 44-46, Vatutin Str., Vladikavkaz, Russian Federation, 362025
}

${ }^{2}$ Southern Federal University, 105/42, Bolshaya Sadovaya Str., Rostov-on-Don, Russian Federation, 344006

${ }^{3}$ North Ossetian Republican Institute for Advanced Training of Educators, 46, Kirov st., Vladikavkaz, Russian Federation, 362027

$\checkmark$ tamertu@mail.ru

\begin{abstract}
The article is devoted to the field modeling of the verbal representation of the stereotypical image of a businesswoman - a new phenomenon in the Russian mentality. A comprehensive description is carried out in the sociolinguistic, linguo-cognitive, discursive and gender aspects based on the integrative cognitive-functional analysis of the linguo-culturally marked components of the stereotype image by the methods of a semantic-cognitive, discursive, contextual, conceptual analysis, the method of field modeling and interpretation of the data obtained. The described fragment of the worldview is a pioneering field of comprehension of new phenomena of reality in the framework of the analysis of business discourse and national conceptual spheres. The empirical material of the study was the results of a survey of professional feminine and masculine groups. The nucleus of the heterostereotype of a businesswoman was revealed, based on the ideas enshrined in the minds of the male entrepreneurs - "feminine strategies of business communication" and an integral set of roles and status positions of the performer and assistant, in which the leading place is given to men, and the secondary - to women. In addition, the analyzed linguistic material demonstrated the transformation of traditional female roles of a wife and a mother towards male roles of a breadwinner and a leader. So, the autoimage of a businesswoman is a complex cognitive structure that includes a set of social roles and functions, numerous gender prescriptions and stereotypes. The nucleus of auto-representations of a businesswoman has also made up a cognitive attribute of "female business communication strategies". The feminine roleplaying set, according to the women entrepreneurs, includes the traditional roles of a housewife, a mother, a wife, a weak woman, a parity spouse and a hybrid feminine-masculine image. According to the study, the actualization of new feminine roles does not eliminate the socio-cultural background of a woman's development in society, but tends to preserve traditional female behavior patterns in combination with components determined by civilizational processes.
\end{abstract}

Key words: gender, stereotype, status-role structure, cognitive attribute, field modeling, linguistic representation of a professional feminine image

Tameryan T.Yu., Zyubina I.A., Dzhigkaeva A.V., 2021

This work is licensed under a Creative Commons Attribution 4.0 International License https://creativecommons.org/licenses/by/4.0/ 
Financing. Acknowledgement

The study was supported by the Russian Foundation for Basic Research, Grant № 19-512-07002 (10-MK/19) "Ossetian-Russian bilingualism in the context of the current ethnopolitical processes: a language picture of the political world and the strategies of political communication"

Article history:

Received: 01.02.2021

Accepted: 15.09.2021

\title{
For citation:
}

Tameryan, T.Yu., Zyubina, I.A. \& Dzhigkaeva, A.V. (2021). Thematic Representation and LinguoCognitive Structure of the Businesswoman Image from the Perspective of Gender-professional Axiology. RUDN Journal of Language Studies, Semiotics and Semantics, 12(4), 1216-1235. doi: 10.22363/2313-2299-2021-12-4-1216-1235

УДК 81"42:338.2:81"27:316.346.2-055.2

\section{Ролевая репрезентация и лингвокогнитивная структура образа деловой женщины в ракурсе гендерно-профессиональной аксиологии}

\author{
Т.Ю. Тамерьян ${ }^{1} \unrhd$, И.А. Зюбина $\mathbb{D}^{2}$, А.В. Джигкаева ${ }^{3}$ \\ ${ }^{1}$ Северо-Осетинский государственный университет им. К.Л. Хетагурова, \\ 362025, Российская Федерация, Владикавказ, ул. Ватутина, 44-46 \\ ${ }^{2}$ Южный федеральный университет, \\ 344006, Российская Федерачия, Ростов-на-Дону, ул. Большая Садовая, 105/42 \\ ${ }^{3}$ Северо-Осетинский республиканский институт повышения квалификации \\ работников образования, \\ 362027, Российская Федерация, Владикавказ, ул. Кирова, 46 \\ \tamertu@mail.ru
}

\begin{abstract}
Аннотация. Статья посвящена полевому моделированию вербальной репрезентации стереотипного образа бизнесвумен - нового феномена в российской ментальности. Комплексное описание осуществляется в социолингвистическом, лингвокогнитивном, дискурсивном и гендерном аспектах на основе интегративного когнитивно-функционального анализа лингвокультурно маркированных составляющих образа-стереотипа методами семантическо-когнитивного, дискурсивного, контекстуального, концептуального анализа, метода полевого моделирования и интерпретации полученных данных. Описываемый фрагмент картины мира представляет собой пионерскую область осмысления новых явлений действительности в рамках анализа делового дискурса и национальных концептосфер. Эмпирическим материалом исследования послужили результаты опроса профессиональных фемининных и маскулинных групп. Выявлено ядро гетеростереотипа бизнесвумен, на основе представлений, закрепленных в сознании мужчин-предпринимателей - «фемининные стратегии бизнескоммуникации» и интегральный набор ролей и статусных позиций исполнителя и помощника, в которых лидирующее место отводится мужчинам, а вторичное - женщинам. Кроме того, проанализированный языковой материал продемонстрировал трансформацию традиционных женских ролей жены и матери в сторону мужских ролей добытчика и лидера. Итак, автообраз бизнесвумен представляет собой сложную когнитивную структуру, включающую набор социальных ролей и функций, многочисленных гендерных предписаний и
\end{abstract}


стереотипов. Ядро автопредставлений бизнесвумен также составил когнитивный признак «женские стратегии бизнес-коммуникации». Фемининный ролевой набор, по мнению предпринимательниц, включает традиционные роли хозяйки дома, матери, жены, слабой женщины, паритетной супруги и гибридный фемининно-маскулинный образ. Как зафиксировало исследование, актуализация новых фемининных ролей не элиминирует социокультурный фон развития женщины в социуме, а тяготеет к сохранению традиционных женских моделей поведения в сочетании с компонентами, обусловленными цивилизационными процессами.

Ключевые слова: гендер, стереотип, статусно-ролевая структура, когнитивный признак, полевое моделирование, языковая репрезентация профессионального фемининного образа

\section{Финансирование. Благодарности}

Исследование выполнено при поддержке РФФИ, грант № 19-512-07002 (10-МК/19) «Осетинско-русский билингвизм в контексте этнополитических процессов нового времени: языковая картина политического мира и стратегии политической коммуникации»

\section{История статьи:}

Дата поступления: 01.02.2021

Дата приема в печать: 15.09.2021

\section{Для цитирования:}

Tameryan T.Yu., Zyubina I.A., Dzhigkaeva, A.V. Thematic Representation and Linguo-Cognitive Structure of the Businesswoman Image from the Perspective of Gender-professional Axiology // Вестник Российского университета дружбы народов. Серия: Теория языка. Семиотика. Семантика. 2021. Т. 12. № 4. С. 1216-1235. doi: 10.22363/2313-2299-2021-12-4-1216-1235

\section{Introduction}

Social-historical transformations in the modern Russia, which began in the 1990s of the twentieth century, led to the formation of a new social-gender group businesswomen. With the revision of the Soviet culture-specific concepts and traditional prescriptions determining the social roles of women in society, as well as in the face of feminization and leveling of gender barriers, both on the basis of biological and social-cultural determination, there has been a modification of the spheres of women's activity - their exit from mainly family and household activities to the field of industrial and entrepreneurial relations.

The emerging and entering the sphere of typification and stereotyping new socio-cultural phenomena in modern conditions of globalization are the most attractive for modern linguistic and interdisciplinary areas of research. This article is no exception: it is based on "cutting edge empiricism" that sheds light on the transformation of cognitive paradigms in modern society. All of the above factors determine the relevance of the problems of this article.

In modern socio-cultural studies, gender, as well as its socio-role and linguistic and discursive representations, is considered as a dynamic, permanently modifying phenomenon of personal identification in various social groups and human society as a whole. Socio-cultural stereotypes that exist and actually form the basis of the common space of perception and understanding are the basis on which the secondary communicative behavioral system is built $[1-4]$. 
The aim of the study is a complex sociolinguistic, linguistic-cognitive and discursive modeling of the stereotypical image of a businesswoman as an explicator of a new phenomenon in the linguistic consciousness of the Russians.

In order to achieve the goal set in the study, we resorted to a survey of men and women entrepreneurs -25 people, respectively.

Recently, a sufficient number of sociological and psychological studies have been devoted to such a phenomenon as a woman in business, published in reputable scientific journals, in publications covering business issues, in women's magazines, and in the many-sided space of the Internet. The Institute of Public Opinion "Anketolog", the Levada Center and the All-Russian Center for the Study of Public Opinion revealed the attitude of the Russians towards women in business. These surveys are a synchronous cross-section reflecting social stereotypes about women entrepreneurs that were relevant at the time of the study.

Modern gender stereotypes in Russia appear from the patriarchal functions of men and women rooted in Russian consciousness, and, in addition, these views are supported by scientific knowledge about the somatic, psychological and communicative characteristics of femininity and masculinity.

By feminine gender stereotypes, we mean simplified, stable, emotionally colored images of behavior, character traits, social roles and status positions enshrined in society [5]. They naturally include in the stereotypical complex positive and negative axiology based on real facts or fictitious ideas. Feminine stereotypes prescribe certain family and professional roles to women and outline the desirable limits of status growth. Thus, the woman was assigned a secondary role as a keeper of the family hearth, and her space was outlined within the boundaries of housekeeping and raising children. While the destiny of the man was proclaimed professional occupations and politics.

In any society, each person implements a certain set of statuses [6], among which a key, as a rule, professional status stands out (there are also distinguished an ethnic / national / racial status, gender status, social origin status, group status, and others) with which a person is identified - it is the main identifier of a person in society.

The concept of a social status is associated with the social roles of an individual. The role-playing theory of personality put forward by J. Mead and R. Linton in the first half of the last century continues to be developed from the position of socio-psychological approaches [7-12].

Social roles can be learned from childhood or internalized in the process of an individual's development, meanwhile there is a factor of imposing social roles as prescribed norms of behavior [13]. Let us pay attention to the fact that the structure of a person's personality is not limited to a set of statuses and roles, however, in order to model the image of a businesswoman, we resort to these research constructs as the most stable structures.

Gender linguo-cultural studies are carried out mainly in a double focus, involving the identification of the specificity of the unity and opposition of the sexes. This category includes numerous studies that identify the features of gender 
representation at different levels of language systems, in particular, the area of innovation-feminitives and the representation of gender through phraseological material are of the greatest interest.

The business sphere has attracted the attention of linguists quite recently [1416], since private entrepreneurship, which had been deactivated in Russia in the period after a new economic policy which was pursued in the 1920s in Soviet Russia and the USSR, began to revive only at the end of the last century.

'Kupets' (in Russ.), that is a merchant, is the first image of an entrepreneur presented in linguoculturological studies in the diachronic sense as the most striking figure, captured in the Russian prose, drama, folklore, and author's tales [17. P. 276-297].

In the treasury of the concept's value, images of such merchants-patrons of the mid-19th - early 20th centuries, who made a significant contribution to the development of the Russian art, literature and science, have been preserved. The merchant is one of the historical predecessors of the businessman.

Personal types 'English businessman' [18; 19] and 'American businessman' [20] as culturally significant concepts have received wide coverage in a number of fundamental studies. The image of a businessman in terms of his communicative behavior, based on press materials, highlighted the characteristics that are valuable for American culture, among which priority is working, self-respect and recognition of merits in society, ambitions as an incentive for growth and development, and a decent environment - a stereotypical set of necessary conditions for the realization of the American dream concerning a successful career building.

The analysis of the business and intellectual qualities of the concept of "entrepreneur" in works on ways to actualize the nuclear components of the stereotype image of 'a businessman' can also be considered paradigmatically related to the research of professional conceptualization [21;22], which mark the transition to general civilizational, globalized spaces of stereotyping. Moreover, the specificity of gender leveling in the conceptual field of the nomination of a person opens up prospects for the study of 'primordially masculine efficiency' in feminine representation. Thus, the portrait of a business person is a cast of the functional and pragmatic characteristics of the business community at the beginning of the 21 st century.

For the first time, an attempt to describe a businesswoman was carried out on the material of the German and Russian-language media in the work of I.F. Badanyan, who repeatedly emphasized the broad influence of precedent media texts as a phenomenon of mass culture on the formation of linguo-cultural types, noting that stereotypes about a business woman in the linguistic consciousness of the Russians and Germans are culturally and historically conditioned [23] in a number of other studies $[24 ; 25]$.

\section{Heterostereotypical modeling of the image of a businesswoman}

In modern Russia, the transformation of gender ideology is gradually taking place, when women expand the legal boundaries of their roles and make a career, 
and men, yielding privileged positions, sometimes switch to female roles, raising children and doing housework, especially in a situation where a female spouse has a higher income.

The heterogeneous image of a businesswoman is analyzed based on a survey of businessmen about women entrepreneurs, in which the businesswoman was characterized by her experience of interacting with them in the business sphere. The description is based on the text fragments extracted from the mass media and specialized sites, blogs, and live journals. The structure of the hetero-image and its semantic content are modeled on the basis of 156 representations.

As a result of processing the revealed verbalizations, there was built a classification based on 16 cognitive features.

Female business communication strategies (25): agility; charm; using female tricks; finding loopholes; feminine ways to succeed in business; female approaches; being pleasant to talk to; knowing how to benefit; ability to orientate correctly; keeping everything under control; transferring the role of the mother to a team of a company; perfectionism; checking everything personally; inability to delegate authority to subordinates; it is difficult for them to negotiate with men on equal terms; knowing everything about subordinates; women are more attentive and kind; honest relationship; bringing comfortable atmosphere; being consistent and systematic, unlike men; emphasis on their own intuition; ability to find compromises; ability to negotiate.

Spheres of women's business (20): small and medium business; industry of beauty and cosmetology; model business; sports industry; culinary business; services in the field of education; service services; hotel business; travel business; catering business; marketing campaigns; media agencies; advertising agencies, business in the field of consumer goods manufacturing; pharmaceutical firms; medical centers; retail; creative centers and associations; accounting firms; legal services.

Attitude towards women's business (15): the world of business is the world of men; the secondary role of women; business is a male prerogative; on the periphery of big affairs; increasing the share of women in business; women find their niche; restrictions on the activities of women; there are pluses and advantages over a man; difficulties in achieving success; the market is aggressive and violent for women; weak analytics; a woman inevitably loses in business; it is difficult to accept that a woman is as competent as a man; success only in some areas of business; the role of a business assistant is more suitable.

Character traits necessary for doing business (14): businesslike; initiative; honest; responsible; the business interests are above all; strong-willed; energetic; fighter for her interests; tact; intelligence; softness; communication skills; leadership qualities; hidden inner strength.

Intra-familial relations (14): the role of a wife and a mother; domestic chores; additional domestic chores inhibit activity; difficult family relationships; a woman is dependent on her family, so she will not be able to fully devote herself to work; a wife spends the day and night at work; the wife earns more; she does not know 
how to improve family relations; constant employment at work; lack of energy and time for a family; relationships with loved ones deteriorate; lost contact with children; they do not communicate with their husbands; family disagreements.

Personal characteristics of a businesswoman (13): a self-confident ladylike; feminist inclinations; emancipé; domineering; she is too keen on work; aggressive; irritable; conflict; a strong character; independent; freedom-loving; the Iron Lady; an energetic woman.

Marital status (12): married; married and has children; married and has no children; divorced and lives with children; divorced and children live with an ex-husband; remarriage; lonely; has a friend; difficult to get married; a widow.

Psycho-emotional state (11): psychological problems; a large number of problems; personality problems; it is difficult to keep cool; they are not sure about their attractiveness; a fear of being a wife; a fear of loneliness; she is afraid of losing freedom; she is afraid of self-control; she attracts weak men; she does not know feminine methods of communication with men; she behaves like a man.

Life priorities (8): personal growth is the main thing in life; career building; succeed in business and family relationships; inclined towards traditional family values; keep the balance; they value home comfort very much; strive to have children.

Physical condition (8): great physical activity; overstrain; they cannot afford a cool male game; constant stress; hard work; business trips; chronic overwork; does not know how to relax and rest.

Business principles (8): she is afraid to take risks; in "difficult" situations she does not know how to learn from failures; workaholism; conservative; striving for stability; caution; less ambitious claims for income growth; they bear business failures easier.

Appearance (7): attractive appearance; in an excellent physical shape; sexy; masculine; short hair, pantsuit, male demeanor.

Inter-gender relations in business (6): business does not know gender; men manipulate them; a woman is a figurehead for the company; a reliable partner; compete with men; strive for equality.

Business woman mentality (5): think like men; they do not accept the emotional and physical difference between a man and a woman; logic and thoroughness; except for work she is not interested in anything.

Interpersonal relationships (2): rare dates; communicates little with friends.

Age (1): a lady of Balzac age (between 30 and 40 years of age).

The analysis of the above representations and statistical calculations made it possible to single out the core of the heterogeneous image of a businesswoman, formed by the cognitive features of "women's strategies of business communication" (25) and "the sphere of women's business" (20).

Male entrepreneurs accept the presence of a feminine style of business management (feminine ways of doing business; feminine approaches) and feminine technologies that are effective for business communication (using feminine tricks; finding loopholes; dexterity; knowing how to benefit; correct orientating; ability to 
find compromises; ability to negotiate), as well as the advantages of business partnership with women based on psycho-physiological characteristics (charm; pleasant to talk to; women are more attentive and kind; honest relationships; bring comfort; consistent and systematic, unlike men; emphasis on their own intuition).

In businessmen's opinion, the disadvantages of the female management style include a mixture of social and intra-familial roles (transferring the role of the mother to the company's team; keeping everything under control; perfectionism; checking everything personally; not knowing how to delegate authority to subordinates) and the inability to build parity partnerships (difficulty for them to negotiate with men on an equal footing; not having feminine methods of communication with men).

According to recent studies, the male style of business communication is emotionally neutral and compressively informative, while women establish emotional contact and have an aim to construct an affiliate type of relationship $[26 ; 27]$.

The introduction of women into the traditionally masculine world of business, especially at the initial stage of the development of new economic relations, gave rise to pretensions among business women for the implementation of male roles, competition and struggle instead of developing feminine methods of communication in a new field, consistent with gender stereotypes.

The introduction of women into the traditionally masculine world of business, especially at the initial stage of the development of new economic relations, gave rise to pretensions among businesswomen for the implementation of male roles, competition and struggle instead of developing feminine methods of communication, consistent with gender stereotypes.

Traditional male dominance manifested itself in an attempt to outline the boundaries of female activity within the framework of "spheres of women's business" (19): businesswomen were restricted in the analyzed materials by 17 types of small and medium-sized businesses. The collected empirical material confirms the existence of a gender-status pyramid in entrepreneurship, according to which, at the top of this hierarchical structure, the proportion of women is quite low.

The near periphery is composed of the following features: "attitude to women's business" (15), "character traits necessary for doing business" (14), "intra-familial relations" (14), "marital status" (12), "psycho-emotional state" (11), "personal characteristics of a businesswoman" (11).

Gender discrimination manifests itself at the level of attitudes towards women's business, when the leading role of men is openly proclaimed (the world of business is the world of men; the secondary role of women; business is a male prerogative; restrictions on women's activities; on the periphery of big affairs; difficulties in achieving success; the market is aggressive and cruel for women; a woman inevitably loses in business; the role of an assistant in business is more suitable). But the inertia of male conservatism is already weakening, albeit with reservations, and the presence of a female niche in business, where a businesswoman is more successful than men, is becoming undeniable (an increase 
in the proportion of women in business; they find their own niche; there are pluses and advantages over a man; success is only in some areas of business; the role of a business assistant is more suitable). However, men admit that it is not always possible to erase gender stereotypes (it is difficult to accept that a woman is as competent as a man).

Noting the character traits necessary for doing business by a business woman, men name the predominant number of qualities correlated rather with the male role (businesslike; initiative; responsible; having business interests above all; strongwilled; energetic; a fighter for her interests; having leadership qualities; having hidden inner strength) than with the female role (tact; intelligence; gentleness; honesty).

Men note that in intra-familial relations the traditional role of a wife and a mother is still in disharmony with a business activity (the role of a wife and a mother; house work; additional domestic chores inhibit activities; a woman is dependent on the family, therefore she cannot fully devote herself to work; she does not know how to improve relationships in her family; lack of strength and time for the family; relationships with loved ones deteriorate; the contact with children is lost; they do not communicate with husbands; family disagreements), and maneuvering between models of female and male behavior (a wife earns more; day and night a wife is at work; constant being busy at work) does not bring satisfaction.

The marital status of a business woman is variable (married; married, has children; married, has no children; divorced, lives with children; divorced, children live with an ex-husband; remarried; single; widow); difficulties with finding a partner (it is difficult to get married) are obvious.

The psycho-emotional state of a business woman, according to men, is extremely controversial. Just as in the modeling of auto-stereotype, it was found that the cognitive sign "psycho-emotional state" is objectified by means of a number of sub-concepts:

- "emotional mood" (it is difficult to maintain composure; she attracts weak men; she behaves like a man; she is not sure of her attractiveness);

- "fear" (a fear of the role of a wife; she is afraid of losing freedom; she is afraid of self-control);

- "mental attitude" (psychological problems; a large number of problems; personality problems).

The idea of a two-career marriage has not yet taken root in the minds of men, therefore there are "costs" in the form of the role of a woman-man, reflected in a negative assessment of the personal characteristics of a business woman (a selfconfident ladylike; feminist inclinations; emancipation-like; domineering; is too fond of work; aggressive; conflict; a strong character; independent; freedomloving).

The far periphery is structured by the following cognitive features: "life priorities" (8), "physical condition" (8), "principles of doing business" (8), "appearance" (7), "inter-gender relations in business" (6), "mentality of a business woman" (5), "interpersonal relations" (2), "age" (1). 
The life priorities of business women, both in terms of the content of women's statements and those of men, are the same: career advancement (personal growth is the main thing in life; building a career; to succeed in business) and harmonious marriage and family relations (to succeed in relationships; tendency to traditional family values; they value home comfort very much; they are eager to have children).

Men point out rightly that the physical condition of a business woman is complicated by non-female burdens (heavy physical loads; overstrain; they cannot afford a cool male game; constant stress; hard work; business trips; she does not know how to relax and have a rest).

Businessmen identified the basic feminine principles of doing business caution (being afraid to take risks) and insufficient analyticism (in "difficult" situations, she does not know how to learn from failures), stating that women are quite excellent performers and assistants (workaholism; conservative; striving for stability; fewer ambition claims to income growth; more easily bear business failure) than courageous entrepreneurs.

The appearance of the businesswoman received an ambivalent assessment: their image is more correlated with the male role (masculine; short hair, pantsuit, male demeanor) than the female (attractive appearance; sexy).

The opinions of men about inter-gender relations in business are contradictory: on the one hand, gender equality is accepted (business does not know gender) with the proviso that women's position in business is secondary (men manipulate them; a woman is a front person for the company), on the other hand, a businesswoman can be confidently cooperated with (a reliable partner; striving for equality).

The mentality of a business woman is focused on career advancement, where they are oriented on the male leadership role (they think like men; do not accept the emotional and physical difference between a man and a woman; except for work, they are not interested in anything).

Such an overloaded life schedule naturally leads to a lack of communication, represented on the basis of the cognitive attribute "interpersonal relations" (she communicates little with friends). As a rule, middle-aged women occupy confident positions in entrepreneurial activity, which was recorded in the framework of the cognitive attribute "age" (a lady of Balzac age).

\section{Autostereotypical modeling of the image of a business woman}

Verbalization of the cognitive model of a businesswoman's autoimage. Modeling of the structure and content of the autoimage of a businesswoman is undertaken on the basis of processing text fragments of interviews with businesswomen.

We have identified 187 representations of the autostereotype of a businesswoman structured on the basis of 17 cognitive features.

Women's business communication strategies (41): everything needs to be controlled; is used to relying on herself; I provide for myself; the ability to make unpopular decisions; tend to avoid complex tasks; strive for cooperation; looking for co-founders and partners; I easily ask for help or advice; quickly admits that she is 
wrong; gathers like-minded people; counts on support; are patient with people; the specifics of managing a women's team; thrift and economy; ability to adapt to partners; ability to speak as a man; tough leadership style; to apply female charm; to treat business like your own child; I perceive my employees as one big family; a woman is trying to create a family within her team; to pay attention to every little thing; I absolutely do not take loans; to find your niche; to set goals correctly; to compromise; do not deviate from the plan; always to keep promises; to be able to be flexible; responsiveness to the problems of subordinates; to calculate every step; sober calculation; looking for a way out of any situation; do not make rash decisions; you must be able to communicate; tact; be a diplomat; do not stop; be ready for certain hardships for the sake of enterprise development; set a high bar for herself; it is necessary to act in one direction concretely; to look for new ways of business development.

Psycho-emotional state (26): it is terrible to be disgraced; a fear that if it does not work out, we will live in poverty; constraint by conventional wisdom; a fear is the biggest motivator; it is scary to change; I'm afraid not to cope; I'm afraid that business will consume me; a fear of moving forward; there were no fears; not be afraid of difficulties; annoying constant phone calls and conversations; stressful situations; constant stress; looking for the positive; there is no incentive to promote the business; is not used to sharing with her problems and difficulties; lived by the principle: there is a task, it is necessary to solve it; the main thing is to have motivation; to have the right motivation; not to quit what you started; not to act under the influence of emotions; continuous emotions; it is difficult to suppress natural softness and become tough; every day I do what I love and get paid for it; it is more difficult for a woman to earn her authority and a name than it is for a man.

Character traits necessary for entrepreneurship (22): confidence in success; leadership skills; purposefulness; determination; proactive; responsibility; male character; strong personality; meticulous; bold; an independent woman; honest; tough; flexibility; ambition; exactingness to herself; hard work; composure; dedication; active; self-organization; self-discipline.

Intra-family relations (18): is supported by the husband; the husband supported her until doing business affected the children and the home; housekeeper; there is practically no time and effort for a family; I devote little time to children; the firm takes a lot of time and effort; I am almost never at home; I communicate only on WhatsApp Web; constantly busy; I appreciate the family hearth; I do not mind doing household chores; I hardly see any relatives; the children are with a nanny; hired tutors; no time for herself; my husband and child feel lack of my love; time management skills in family matters.

Reasons for doing business (13): business is a means of earning money; selfrealization; for the sake of achieving my goal; independence from the employer; I want to have my own business; to improve the financial situation; to realize myself; material difficulties; money appeared to start my own business; to realize my creative ideas; to apply professional skills; to get a profit; to work for myself. 
Physical condition (11): overstrain, constant fatigue; I work late; prostration; huge pressure; I have no energy; I need to keep good-looking; I try to take care of my health; to eat correctly; to do sports; I must relax.

Problems of doing business (10): I work hard, but I have not made a profit yet; income is negative; sabotage of workers; I started my business on maternity leave, looking for spare time; there were moments when there was no time to eat or sleep; I slept for three hours a day; I worked non-stop; I started from scratch; there was no support; there was zero money; business is in transition.

Pastime (9): I try to attend interesting events; I do shopping; I go to yoga; I'm doing fitness; I try to get enough sleep; I keep fit; hobby; I allow myself SPA, massages, beauticians; I arrange small pleasures.

Intergender relations in business (7): my husband and I are business partners; men do not perceive women as a business partner; men do not perceive a woman as an equal partner; women strive for equality in relationships; a woman must prove that she is better than a man in something; no gender preferences for employees; it's easier to work with men.

Interpersonal relationships (7): lack of non-business communication; stable friendly contacts; personal life is not so good; is selective; needs a strong man; it is difficult to find a balance between personal and business spheres.

Life priorities (6): to start a family in the middle of a career path, when I have already got on my feet, but there is still room to grow; having children makes it difficult to run a business and a successful career; to be realized in the family and in business; to distribute forces between career and raising children; I want harmony in life; I want to have a fulfilling life.

Intellectual abilities (6): education; smart; intelligence; professionalism; literate; she always learns something new.

Appearance (4): attractive; interesting; women start looking not so good.

Marital status (4): more often single; they want to have a family and children; they are married and have children.

Charity as a business principle (3): helping others; one good deed a day; if you help others, you will achieve more; to enjoy being able to help others.

As the above data demonstrate, the center of the nuclear part of the concept of 'a business woman' naturally formed the most frequent cognitive feature - 'female strategies of business communication' (41). Its linguistic explication demonstrates the directions of the adaptation process of women to the field of entrepreneurship through the roles of a housewife (thrift and economy; to be able to be flexible; to pay attention to every little thing; I categorically do not take loans), of a mother (to treat business like her own child; I perceive my employees as one large family; a woman is trying to create a family within her team), of a wife (to find her niche; ability to adapt to partners; it is common to avoid difficult tasks; strive for cooperation; look for co-founders and partners; responsiveness to the problems of subordinates; to be ready for certain hardships for the sake of enterprise development), of a weak woman (using female charm; tactfulness; she easily asks for help or advice; she quickly admits that she is wrong; she gathers like-minded 
people; she counts on support; being patient with people; being a diplomat; compromising) and the role of 'a woman- man' (speaking masculine; tough leadership style; is used to relying on herself; I provide for myself; to set a high standard for yourself; to look for new ways of business development; sober calculation).

The core zone of the stereotype of a businesswoman is represented by 3 cognitive signs, one of which is "psycho-emotional state" (26) that marks the psychological and emotional difficulties arising in a woman moving in a new direction for herself. Verbalization of the declared feature is realized through such sub-concepts as:

- 'emotional mood' (not to act under the influence of emotions; continuous emotions; it is difficult to suppress natural softness in myself and become tough; stressful situations; constant stress; looking for positivity; constraint by generally accepted opinions; annoying constant phone calls and conversations; every day I do something that I love and get paid for it);

- 'fear' (it is scary to embarrass myself; a fear that if it does not work out, we will live in poverty; a fear is the biggest motivator; being scared to change anything; I am afraid not to cope with the task; I am afraid that business will swallow me; a fear of moving forward; there were no fears; not to be afraid of difficulties);

- 'psychic attitude' (there is no incentive to promote the business; I was not used to sharing with my problems and difficulties; I lived by the principle: there is a task, it is necessary to solve it; the main thing is to have motivation; to have the right motivation; not to quit what she started; it is more difficult for a woman to earn her authority and name than a man).

The objectification of the cognitive attribute 'character traits necessary for entrepreneurship' (22) is largely consistent with the new role of 'a woman-man' (confidence in success; leadership qualities; purposefulness; decisiveness; proactive; responsibility; masculine character; strong personality; brave; an independent woman; honest; tough; ambitions; composure; selflessness; active; self-organization; self-discipline), purely feminine manifestations of personality (meticulous; flexibility) and universal values (honest; hard work; selfexactingness).

'Intrafamily relations' (18) are assessed by a business woman from the standpoint of a traditional feminine model of behavior, according to which an entrepreneur confirms that it is almost impossible to run a business and remain an exemplary mother and wife according to old stereotypes (her husband supported her until doing business affected the children and the house; there is practically no time and effort for the family; little time is given to children; the company takes a lot of time and effort; I am practically never at home; I communicate only on WhatsApp Web; I am constantly busy; she appreciates the family hearth; she does not mind doing household chores; I hardly see relatives; I have no time for myself; my husband and child feel lack of my love). However, the condemnation of herself as a bad wife, mother, and mistress, correlated with the patriarchal way of life, begins to give way to the awareness of gender equality, that is the parity of spouses 
(the children are with a nanny; I hired tutors; a housekeeper; my husband supports; time management skills in family matters), which indicates mental restructuring and the initial stage of internalization of the new role.

The near periphery is structured by the cognitive features of "reasons for doing business" (13), "physical condition" (11) and "problems of doing business" (10).

Among the reasons for doing business, there are three criteria indicators that show a change in attitudes towards gender roles in the mass consciousness:

1) self-realization (to realize my creative ideas; to apply professional skills; to make a profit; self-realization; for the sake of achieving my goal; to realize myself);

2) a means of earning (a means of earning, to improve the financial situation; material difficulties);

3) self-sufficiency and independence (independence from the employer; I want to have my own business; to work for myself; money appeared to start my own business).

Recognizing that it is not always possible to regulate the schedule of her employment (overexertion, constant fatigue; I work late; lack of energy; heavy burden; no energy), a businesswoman comes to the realization that a woman should not sacrifice herself, and that it is necessary, in first of all, to take care of your physical condition (you need to keep good-looking; I try to take care of my health; to eat right; to do sports; I must relax).

In modern society, the financial independence of women is becoming a normal practice, therefore, significant efforts are required in a new field, which, of course, does not do without the problems of doing business (I work intensively, but I have not made a profit yet; income is negative; sabotage of employees; I started a business on maternity leave, looking for spare time; there were moments when there was no time to eat or sleep; I slept for three hours a day; I worked non-stop; I started from scratch; there was no support; there was zero money; business is in a transitional stage).

The periphery of the stereotypical image of a businesswoman on the claimed material was made up of the cognitive features of 'pastime' (9), 'intergender relations in business' (7), 'interpersonal relations' (6), 'life priorities' (6), 'intellectual abilities' (6), 'charity as a business principle' (3), 'appearance' (4) and 'marital status' (4).

The pastime of a business woman is aimed at outdoor activities, relieving stress, maintaining an image and taking care of health (I try to attend interesting events; I do shopping; I go to yoga; I do fitness; I try to get enough sleep; I keep fit; a hobby; I allow myself SPA, massages, a cosmetologist; I arrange small joys).

Intergender relations in business are implemented as a parity type of interaction (my husband and I are business partners; there are no gender preferences for employees; women strive for equality in relationships), at the same time, the old model of gender inequality works (men do not perceive a woman as a business partner; men do not perceive a woman as an equal partner; a woman must prove that she understands something better than a man) and psycho-gender peculiarities of interaction are revealed (it is easier to work with men). 
The sphere of interpersonal relations is not so clearly manifested in an interview with a businesswoman, however, it is obvious that being very busy leads to a limitation of communication, while maintaining old connections (lack of nonbusiness communication; stable friendly contacts). Unconditional difficulties consist in balancing all aspects of life and in finding a man of equal personal qualities for marriage (personal life is not so good; being selective; she needs a strong man; it is difficult to find a balance between personal and business spheres).

Life priorities (6) of a businesswoman are consistent with the general trend not only towards building a career as a priority task in the modern world (starting a family in the middle of a career path, when she is already on her feet, but there is still room to grow; having children complicates business and a successful career), but also the creation of harmonious family relationships (to be realized in the family and in business; to distribute forces between a career and raising children; I want to have a full life).

High intelligence (6) of a business woman takes a peripheral position in the structure of the concept as a self-evident fact (education; being smart; intelligence; professionalism; she always learns something new).

The appearance (4) of a businesswoman is of little importance to her, although most often the image of a businesswoman corresponds to her position in society (attractive; interesting), with the proviso that she lacks time to maintain an appropriate appearance (women start looking not so good).

Marital status (4) of a businesswoman is variable (more often they are single; they want to have a family and children; they are married and have children).

The cognitive attribute 'charity as a principle of doing business' (3) in the structure of the autoimage of a businesswoman arises from the traditional gender opposition, where a man is a "breadwinner / protector" and a woman is a "housewife." It is the female functions that include the moral, emotional and psychological support of the family members, concern for their spiritual enrichment, which are transferred to the social sphere, where the proportion of women engaged in charitable activities is naturally higher than that of men (helping others; one good deed per day; if to help others, you will achieve more; enjoy the fact that you can help others).

So, the autoimage of a businesswoman is a complex cognitive structure that includes a set of social roles and functions, numerous gender prescriptions and stereotypes.

\section{Conclusion}

Thus, on the basis of the described empirical material, we identified an integral set of roles of a business woman, fixed in the minds of male entrepreneurs in the form of standard schemes, models of thinking and value judgments. Status positions, in which the leading place is given to men, and the second to women, were approved directly and implicitly, since women, according to businessmen, are very good performers and assistants, but not leaders. Women are also assigned a 
specific sector of activity associated with the traditional distribution of labor. Caution and lack of analyticism were cited as typical manifestations of feminine principles of business management.

In business inter-gender relations, against the background of secondary status and gender inequality, the reliability of cooperation with a business woman is declared.

The feminine role-playing set, according to the position of men, is based on a mixture of the social and intra-family roles: women maneuver between the traditional roles of a wife and a mother, on the one hand, and the male role of a breadwinner and a leader, that is, the hybrid role of a woman-man, striving to realize more fully masculine qualities than feminine, which is frowned upon by businessmen.

The mentality of business representatives of the weak sex is biased towards the implementation of masculine tasks, despite biological differentiation.

The unstable psycho-emotional state of the business woman as a result of the combination of multifunctional role-playing pragmatics connects the content of the hetero-stereotypic component of the lingual-cultural type with the relevant subconcepts: "emotional mood", "fear" and "mental attitude".

The physical condition of the business woman represents the concept of "stress".

At the same time, men note the desire of women for the ideal - the establishment of a harmonious balance between the business and family spheres.

In the appearance of a business woman, according to the judgments of male entrepreneurs, masculinity is more manifested than femininity.

The basis of the businesswoman's ideas about themselves was formed by the cognitive attribute "women's strategies of business communication".

The role-playing set of the stereotype image, according to the entrepreneurs, includes the traditional roles of a housewife, a mother, a wife, a weak woman, the hybrid image of a woman-man, and the new multifunctional role of a parity wife.

The dominant cognitive attribute "psychoemotional state" reflects the difference in male and female models of thinking: if the male model is "speech - logic emotions", then in the female model, emotions outrun logic: "speech - emotions logic". The explication of the cognitive attribute "psycho-emotional state" affects the conceptual layer of emotions, appealing to such sub-concepts as: "emotional mood", "fear" and "mental attitude".

The transformation to a new gender position is manifested in the motivations that prompted women to take up business: the desire for self-realization, independence and a way of earning money to provide for the family on an equal basis with men.

On the same principles of equality, women strive to build interactions with male partners, although old gender stereotypes are breaking down slowly and the final transition to a new social role of a business woman has not yet materialized: at the moment there is a so-called "double message" when business women act in two models of behavior - female and male. This is confirmed by the life priorities of a business woman, combining male and female vectors of development: building a career and creating harmonious family relationships. 
The implementation of charitable projects aimed at helping the poor, the disabled, in dire need of medical care is, first of all, the merit of women entrepreneurs, which is consistent with the roles inherent in female nature.

Thus, the emergence of such a complex phenomenon as women's entrepreneurship is associated with the transformation of the value-orientated system in modern society, as well as the modification of the socio-cultural space, which reflects in the linguistic consciousness qualitative changes in social formations that previously adhered to traditional models of behavior. The transitional, still unstable position of women in the modern business space was described on the basis of extensive empirical material and this position demonstrated the complex, integral set of social roles of a businesswoman identified by us.

\section{References}

1. Lippman, W. (2004). Public opinion, T.V. Barchunova (trans.). Moscow: Institute of the Public Opinion Foundation. (In Russ.).

2. Eriksson, T., Smith, N. \& Smith, V. (2017). Gender Stereotyping and Self-Stereotyping Attitudes: A Large Field Study of Managers. Bonn: IZA Institute of Labor Economics. IZA Discussion Paper, 10932.

3. Kachmazova, A.U. \& Tameryan, T.Yu. (2017). Ethnic space of linguistic stereotyping "friendfoe-friend". Vladikavkaz: SOGU. (In Russ.).

4. Popova, Z.D. \& Sternin, I.A. (2007). Cognitive linguistics. Moscow: AST "East-West". (In Russ.).

5. Vorontsov, D.V. (2010). Gender socialization. Gender psychology: chrestomathy. Irkutsk: ISU. pp. 83-87. (In Russ.).

6. Merton, R.K. (ed.) (1968). Social Theory and Social Structure. New York: The Free press.

7. Murray, H.A. (1938). Explorations in personality. Oxford: Oxford University Press.

8. Biddle, B.J. (1986). Recent Developments in Role Theory. Annual Review of Sociology, 12(1), 67-92.

9. Connell, R.W. (1979). The Concept of Role and What to Do With It. SAGE Journals: Journal of Sociology, 15(3), 116-118.

10. Bodalev, A.A. (1998). Personality and communication. Moscow: International Pedagogical Academy. (In Russ.).

11. Smith, G.W.H. (2005). Enacted Others: Specifying Goffman's Phenomenological Omissions and Sociological Accomplishments. Human Studies, 28, 397-415.

12. Turner, J.H. (2006). Handbook of Sociological Theory. Dordrecht: Springer.

13. Barrett, M. \& Davidson, M.J. (2006). Gender and communication at work: an introduction. In: M. Barrett \& M.J. Davidson (Eds.), Gender and Communication at Work. Aldershot: Ashgate. pp. $1-18$.

14. Kryukov, I.A. (2009). The concept "business" in the concept sphere of the Russian language of the latter (based on the material of the national corpus of the Russian language). Bulletin of Nizhny Novgorod University named after Lobachevsky, 2, 266-269. (In Russ.).

15. Startseva, T.V. (2011). Actualization of the emigrant concept within the gender stereotype of a woman emigrant. Bulletin of the Kemerovo State University, 4(48), 217-224. (In Russ.).

16. Guseva, E.Yu. (2011). Gestalt structuring of the BUSINESS concept as a way to comprehend this fragment of the world in American linguistic culture. Samara University Bulletin. History, pedagogy, philology, 4(17), 143-147. DOI: 10.18287/2542-0445-2011-17-4-143147 (In Russ.).

17. Karasik, V.I. (2009). Language keys. Moscow: Gnosis. (In Russ.). 
18. Mikhailova, A.G. (2004). Linguocultural type "English businessman". In: Axiological linguistics: communicative types. Volgograd: Paradigma. pp. 136-155. (In Russ.).

19. Ilyukhina, M.S. (2012). Parametric characteristics of the linguocultural type "English businessman". Humanities research, 42, 65-69. (In Russ.).

20. Chekaeva, V.V. (2012). Linguocultural type "American businessman": value characteristics. In: Youth and Science: a collection of materials of the VIII All-Russian Scientific and Technical Conference of Students, Postgraduates and Young Scientists, dedicated to the 155th anniversary of the birth of K.E. Tsiolkovsky. Krasnoyarsk: Siberian Federal University. [Electronic resource] URL: http://conf.sfu-kras.ru/sites/mn2012/section28.html (accessed: 05.02.2021). (In Russ.).

21. Ivanova, M.M. (2008). Experimental study of the concept "entrepreneur". Psycholinguistic issues, 7, 97-100. (In Russ.).

22. Dolgova, E.V. (2013). Lexico-phraseological features of the speech genre "portrait of a business person" in the media discourse. Philological sciences. Questions of theory and practice, 3-1(21), 50-53. (In Russ.).

23. Badanyan, I.F. (2016). Cognitive stereotypes that form the concept of "business woman" in a naive picture of the world (based on the material of the Russian and German languages). Bulletin of the Southern Federal University. Philological sciences. P. 2. 204-213. (In Russ.).

24. Tameryan, T.Yu., Zheltukhina, M.R., Zyubina, I.A. \& Buzinova, L.M. (2020). Feminine representation of the business sphere: a communicative-cultural aspect. In: European proceedings of social and behavioural sciences. Proceedings of the II International Scientific and Practical Conference "Individual and Society in the Modern Geopolitical Environment" Conference (ISMGE 2020). Social and Behavioural Sciences. pp. 914-924.

25. Tameryan, T.Y., Popova, T.G., Redkozubova, E.A., Anikejeva, I.G., Sedliarova, O.M. \& Solovyeva, N.S. (2019). Feminine perspective of ethnic business communication. Espacios, 40(34), 18.

26. Rogers, K.B., Schröder, T. \& Scholl, W. (2013). The Affective Structure of Stereotype Content: Behavior and Emotion in Intergroup Context. Social Psychology Quarterly, 76(2), 125-150. doi: 10.1177/0190272513480191 (accessed: 05.02.2021).

27. Tannen, D. (1994). Gender and Discourse. London: Oxford University Press.

\section{Библиографический список}

1. Липпман У. Общественное мнение / пер. с англ. Т.В. Барчуновой. М.: Институт Фонда «Общественное мнение», 2004.

2. Eriksson T., Smith N., Smith V. Gender Stereotyping and Self-Stereotyping Attitudes: A Large Field Study of Managers. Bonn: IZA Institute of Labor Economics. IZA Discussion Paper; Journal. 2017. № 10932.

3. Качмазова А.У., Тамерьян Т.Ю. Этническое пространство языковой стереотипизации «свои-чужие-свои». Владикавказ: СОГУ, 2017.

4. Попова 3.Д., Стернин И.А. Когнитивная лингвистика. М.: АСТ «Восток-Запад», 2007.

5. Воронщов Д.В. Гендерная социализация. Гендерная психология: хрестоматия. Иркутск: ИГУ, 2010. С. $83-87$.

6. Merton R.K. Social Theory and Social Structure. New York: The Free press, 1968.

7. Murray H.A. Explorations in personality. Oxford: Oxford University Press, 1938.

8. Biddle B.J. Recent Developments in Role Theory // Annual Review of Sociology. 1986. Vol. 12. Iss. 1. P. 67-92.

9. Connell R.W. The Concept of Role and What to Do With It // SAGE Journals: Journal of Sociology. 1979. Vol. 15. № 3. P. 116-118.

10. Бодалев А.А. Личность и общение. Избранные психологические труды. М.: Международная педагогическая академия, 1998.

11. Smith G.W.H. Enacted Others: Specifying Goffman's Phenomenological Omissions and Sociological Accomplishments // Human Studies. 2005. Vol. 28. P. 397-415. 
12. Turner Jonathan H. Handbook of Sociological Theory. Dordrecht: Springer, 2006.

13. Barrett M., Davidson M.J. Gender and communication at work: an introduction. In M. Barrett \& M.J. Davidson (Eds.), Gender and Communication at Work, Aldershot: Ashgate, 2006. P. $1-18$.

14. Крюков И.А. Концепт «бизнес» в концептосфере русского языка последних (на материале национпльного корпуса русского языка) // Вестник Нижегородского университета имени Лобачевского. 2009. № 2. С. 266-269.

15. Стариева T.B. Актуализация концепта emigrant в рамках гендерного стереотипа женщина-эмигрант. Вестник Кемеровского государственного университета. 2011. № 4 (48). C. $217-224$.

16. Гусева Э.Ю. Гештальтное структурирование концепта БИЗНЕС как способ осмысления данного фрагмента мира в американской лингвокультуре // Вестник Самарского университета. История, педагогика, филология. 2011. № 4. Том 17. С. 143-147. DOI: 10.18287/ 2542-0445-2011-17-4-143-147

17. Карасик В.И. Языковые ключи. М.: Гнозис, 2009.

18. Михайлова А.Г. Лингвокультурный типаж «английский бизнесмен» // Аксиологическая лингвистика: коммуникативные типажи. Волгоград: Парадигма, 2004. С. 136-155.

19. Ильюхина М.С. Параметрические характеристики лингвокультурного типажа «английский бизнесмен» // Гуманитарные исследования. 2012. № (42). С. 65-69.

20. Чекаева В.В. Лингвокультурный типаж «американский бизнесмен»: ценностные характеристики // Молодёжь и наука: сборник материалов VIII Всероссийской научно-технической конференции студентов, аспирантов и молодых учёных, посвященной 155-летию со дня рождения К.Э. Циолковского. Красноярск: СФУ, 2012. [Электронный ресурс] Режим доступа: http://conf.sfu-kras.ru/sites/mn2012/section28.html (дата обращения: 05.02.2021).

21. Иванова М.М. Экспериментальное исследование концепта «предприниматель» // Вопросы психолингвистики. 2008. № 7. С. 97-100.

22. Долгова Е.В. Лексико-фразеологические особенности речевого жанра «портрет делового человека» в дискурсе СМИ // Филологические науки. Вопросы теории и практики. 2013. № 3-1 (21). С. 50-53.

23. Баданян И.Ф. Когнитивные стереотипы, формирующие концепт «деловая женщина» в наивной картине мира (на материале русского и немецкого языков) // Известия Южного федерального университета. Филологические науки, 2016. С. 2. 204-213.

24. Tameryan T.Yu., Zheltukhina M.R., Zyubina I.A., Buzinova L.M. Feminine representation of the business sphere: a communicative-cultural aspect // European proceedings of social and behavioural sciences. Proceedings of the II International Scientific and Practical Conference "Individual and Society in the Modern Geopolitical Environment" Conference (ISMGE 2020). Social and Behavioural Sciences. 2020. C. 914-924.

25. Tameryan T.Y., Popova T.G., Redkozubova E.A., Anikejeva I.G., Sedliarova O.M., Solovyeva N.S. Feminine perspective of ethnic business communication // Espacios. 2019. T. 40. № 34. C. 18.

26. Rogers K.B., Schröder T., Scholl W. The Affective Structure of Stereotype Content: Behavior and Emotion in Intergroup Context // Social Psychology Quarterly. 2013. Vol. 76. Issue 2. P. 125150. doi: 10.1177/0190272513480191 (дата обращения: 05.02.2021).

27. Tannen D. Gender and Discourse. London: Oxford University Press, 1994.

\section{Information about the authors:}

Tatyana Yu. Tameryan, Doctor of Philology, Professor, Professor of the Department of Foreign Languages for Non-Language Specialties, Faculty of International Relations, North Ossetian State University; scientific interests: general and comparative linguistics, cognitive linguistics, psycholinguistics, anthropological linguistics, theory of discourse and intercultural communication; e-mail: tamertu@mail.ru ORCID ID: 0000-0003-0532-2538; Researcher ID: L-1756-2018; Scopus Author ID: 57110384400. 
Irina A. Zyubina, PhD (Philology), Associate Professor, Associate Professor of the Department of Linguistics and Professional Communication, Southern Federal University, Department of Linguistics and Professional Communication; scientific interests: pragmalinguistics, theory of language, theoretical grammar, theory of speech acts, sociolinguistics, theory of discourse, semantics; e-mail: iazyubina@sfedu.ru ORCID ID: 0000-0002-1265-8366; Researcher ID: J-52052017; Scopus Author ID: 57194704279.

Alla V. Dzhigkaeva, PhD (Philology), Senior Lecturer of the Department of Humanities of the North Ossetian Republican Institute for Advanced Training of Educators; scientific interests: theory of language, theoretical grammar, theory of speech acts, sociolinguistics, theory of discourse, semantics; e-mail: kokowa.alla@yandex.ru

\section{Сведения об авторах:}

Тамерьян Татьяна Юльевна, доктор филологических наук, профессор, профессор кафедры иностранных языков для неязыковых специальностей факультета международных отношений, Северо-Осетинский государственный университет; научные интересы: общее и сравнительное языкознание, когнитивная лингвистика, психолингвистика, лингвокультурология, теория дискурса и межкультурная коммуникация; e-mail: tamertu@mail.ru ORCID ID: 00000003-0532-2538; Researcher ID: L-1756-2018; Scopus Author ID: 57110384400.

Зюбина Ирина Анатольевна, кандидат филологических наук, доцент, доцент кафедры лингвистики и профессиональной коммуникации, Южный федеральный университет; научные uнтересы: прагмалингвистика, теория языка, теоретическая грамматика, теория речевых актов, социолингвистика, теория дискурса; e-mail: iazyubina@sfedu.ru ORCID ID: 0000-00021265-8366; Researcher ID: J-5205-2017; Scopus Author ID: 57194704279.

Джигкаева Алла Владимировна, кандидат филологических наук, старший преподаватель кафедры гуманитарных наук Северо-Осетинского республиканского института повышения квалификации работников образования; научные интересы: теория языка, теоретическая грамматика, теория речевых актов, социолингвистика, теория дискурса; e-mail: kokowa.alla@yandex.ru 